\title{
APPLICATIONS OF DIGITAL IMAGE ANALYSIS (DIA) TO FOOD-QUALITY ASSESSMENT: AN OVERVIEW
}

\author{
Youssef, M.M., Abou-Gharbia, H.A. \& El-Haddad Nessma, N. \\ Food Science \& Technology Dept., Fac. of Agric., El-Shatby, 21545 \\ Alexandria Univ., Alexandria, Egypt
}

\begin{abstract}
Recently, the role of digital image analysis has been grown widely in different technological fields such as, space research, communications, remote sensation, medicine and in analysis, processing and quality assessment of foods.

The term image refers to a two-dimensional light-intensity function, denoted by $f(\mathrm{x}, \mathrm{y})$, when the value or amplitude of $f$ at spatial coordinates (x,y) gives the intensity (brightness) of the image at that point. We may consider a digital image as a matrix whose row and column indices indentify a point in the image and the corresponding matrix element value identifies the gray level at the point. The elements of such a digital image array are called image elements, picture elements, pixels, or pels with the last two names being commonly used as abbreviations of "pictures elements". An expansion in image analysis applications is occurring within the agriculture and food industries with the result that image analysis can be used for the characterization of food products. It is noteworthy that images are often studied for detecting or enhancing geometrical structures.

Image analysis can be used in many aspects of food industry, analysis and quality assurance. For instance, image analysis can be used to discriminate cereal grains and classify cereal kernels according to their physical dimensions. Meanwhile, colour analysis of individual wheat grains might facilitate the identification of grains in the wheat-grading context. Moreover, by selecting the near IR wavelengths of excitation and emission, images obtained can be applied to discriminate starch, gluten and bran which present the three major components of wheat grain. The study of colour or intensity of the points (pixels) in an image can be a way to obtain chemical information, such as fat and lean contents in meat and meat products. In case of minced meat, the fat can be differentiated from lean using UV light. Furthermore, digital image analysis was developed to measure the size and spatial distribution of the satellite microbial colonies as a function of distance from the primary colony.

Bar coding represents an important application of image analysis. Bar coding is a form of artificial identifier. It is a machine readable code consisting of a pattern of black and white bars and space defined ratios which represent alphanumeric character. A sensor scans the bar code symbol and converts the visual image into an electrical signal.
\end{abstract}

Keywords : image analysis, food quality, light intensity, pixels, cereals, bakery products, pasta, noodles, chicken, meat, cheese, chemical constituents, microbiology, sodium bicarbonate, bar code.

\section{INTRODUCTION}

Interest in digital image processing methods stems from two principal application areas: improvement of pictorial information for human interpretation and processing of scene data for autonomous machine perception. One of the first applications of image processing techniques in the first category was in improving digitized newspaper pictures sent by submarine cable between London and
New York in the early 1920s (Gonzales \& Wintz, 1987).

Over the last 15 years, considerable progress has been made in applying digital image analysis (DIA) technologies to solve quality issues in the food industry (Scanlon \& Sapirstein, 2002). The DIA as a highly computerized technique, has many advantages for meeting these tasks compared to subjective visual inspection : it is quantitative, precise, 
accurate, objective and also a rapid technique (Gunasekaran \& Ding, 1994, Sapirstein, 1995). In addition, the continuing acceleration of computing power permits the use of increasingly sophisticated algorithms to reduce the pictorial information within an image into readily assimible results (Scanlon \& Sapirstein, 2002).

According to Galbiati (1990), machine vision and digital imaging technology is multidiscipline in the sense that the field uses of knowledge of traditional engineering and computer programming for the different parts of the process. Machine vision and digital imaging will be a major field of endeavor for professionals in the years ahead. There has been fragmented use of vision technology during the past three decades for space, military and limited industrial applications. Machine vision was not used to a great extent because of the newness of the technology. There was a lack of low-cost, commercially available equipment and a limited supply of individuals with technical knowledge about machine vision.

Digital image or machine vision technology will have a major impact on all industrial tasks in the next decade because the supporting technologies have progressed to the point where the use of this technology is now viable. Three main conditions are necessary for widespread application of a new technology: (1) Reliable hardware at reasonable cost, (2) Individuals who have the hardware and programming knowledge to apply the technology and (3) A need or a problem requiring a solution (Galbiati, 1990).

An illustration of the growth of DIA applications is the number of researchers employing the technique: in 1986, a search of Food Science \& Technology Abstracts using the term image analysis would identify only 6 journal articles for that year, in 2000, the same search yielded 65 journal articles and two patents (Scanlon \& Sapirstein, 2002). Moreover, a book written by Davies (2000) and entitled : "Image Processing for the Food Industry" was published.

What is the Digital Image Anlysis (DIA): A digital image is an image $f(\mathrm{x}, \mathrm{y})$ that has been discretized both in spatial coordinates and in brightness. We may consider a digital image as a matrix whose row and column indices identify a point in the image and the corresponding matrix element value identifies the gray level at that point. The elements of such a digital array are called image elements, picture elements, pixels or pels, with the last two names being commonly used abbreviations of "picture elements" (Gonzales \& Wintz, 1987).

The digital image process can be subdivided into three activities namely: (1) Obtaining the digital representation of an image, (2) Employing computational techniques to process or modify the image data and (3) Analyzing and using the results of the processing for the purpose of guiding robots or controlling automated equipment, assuring a level of quality in manufacturing process, or supporting statistical analysis in a computerassisted-manufacturing (CAM) system (Galbiati, 1990). The components of a basic, general-purpose digital image processing system are shown in Fig. (1).

A simple industrial vision system used for factory automation could be characterized by a single camera monitoring an assembly line as shown in Fig. (2). The vision system observes the object, determines if it is within specifications and generates command signals according to the obtained results. The image acquisition equipment includes the lights, camera and possibly the frame grabber. The processing equipment includes both hardware and software in the vision processing unit, and the output equipment is the electronics interfacing the system to various parts of the manufacturing world (Galbiati, 1990).

It is worth to mention that so many applications of DIA are now available in the area of food industry and quality as well. The most important applications in this respect can be reviewed under the following main headings:

A-Cereals : In 1986, Walter Bushuk was appointed Research Chair in Grain Technology at the University of Manitoba, Canada. A key objective for the Chair's research program was to investigate the feasibility of digital image analysis (DIA) for inspection and grading of wheat grains for purposes of quality identification (Dawson, 1986). At that time the application of DIA to cereal science was an emerging technology, with only three research groups active in primarily grainrelated studies (Scanlon \& Sapirstein, 2002). 


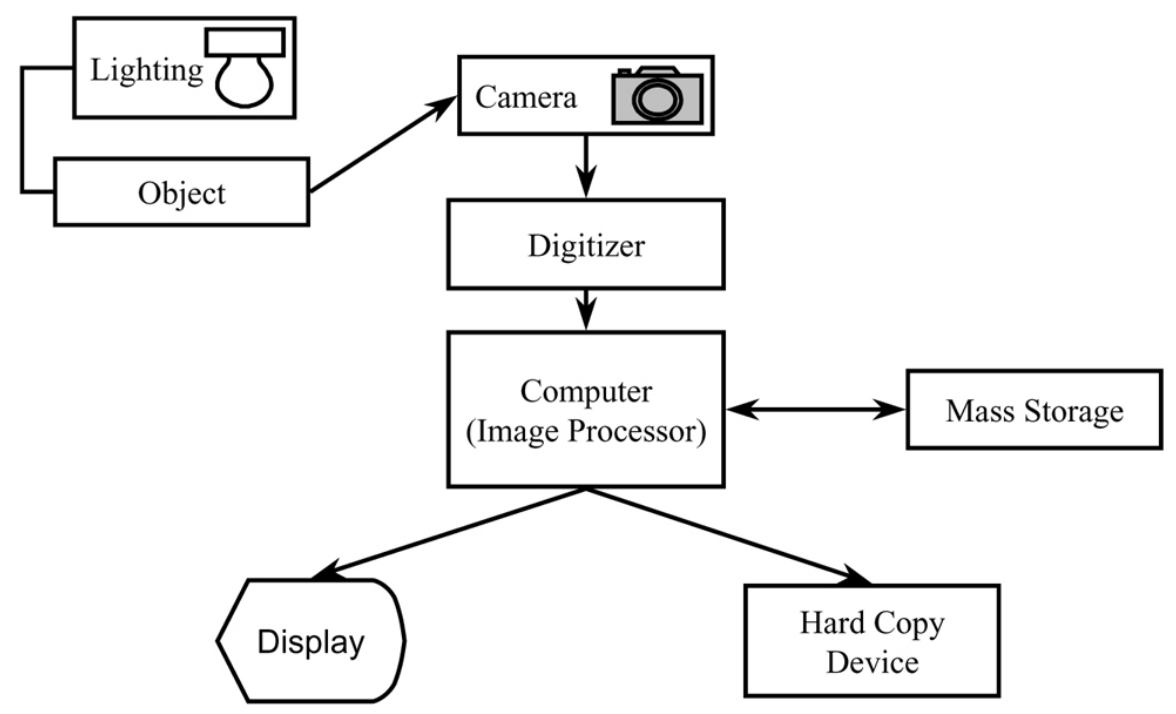

Fig. 1: General elements of machine vision system Ref. Gonzales \& Wintz (1987).

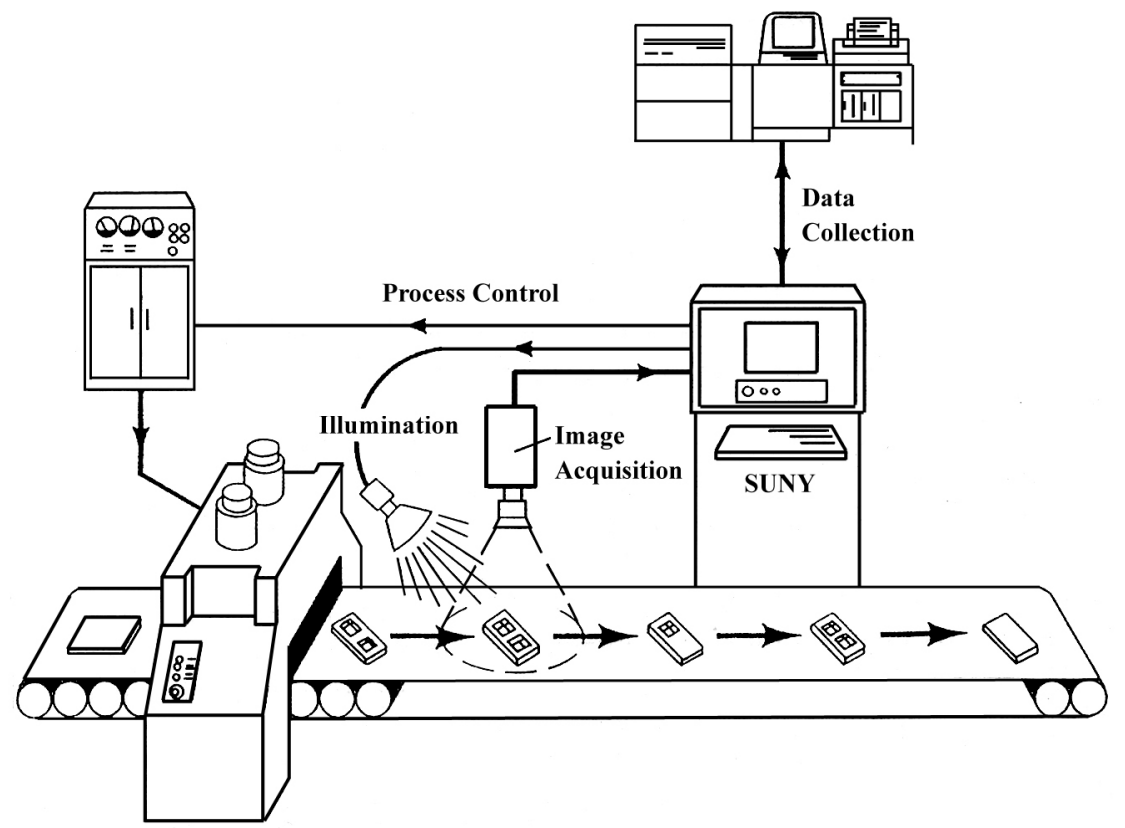

Fig. 2: Industrial manufacturing cell with vision system Ref. Galbiati (1990).

The DIA process can extract visual characteristics that are uniquely related to variety or a group of varieties from the image of the wheat sample in order to classify the properties of the sample (Keefe \& Draper, 1986, Neuman et al., 1987, Symons \& Fulcher, 1988). Various grain characteristics can be employed, such as grain morphology (Symon \& Fulcher, 1988, Majumdar \& Jayas, 2000a), grain reflectance data (Sapirstein \& Kohler, 1995) and grain texture features (Majumdar \& Jayas, 2000b). It is worth to mention that red spring wheat could be assigned correctly into milling grade or poorer quality grades on the basis of parameter variance and mean data computed by DIA (Kohler, 1991). Meanwhile, the ability of DIA to discriminate grains subjected to severe environmental degradation such as sprouting is obviously beneficial from a quality viewpoint (Sapirstein \& Kruger, 1995).

Insect contamination has obvious implications for wheat quality deterioration if the wheat is to be shipped or stored. If insects are hidden within grains, then use of imaging 
methods that operate beyond the visible range confers extra advantages to DIA inspection (Schatzki \& Fine, 1988). A recent review has covered imaging methods for detecting contaminations in food utilizing techniques within and beyond the visible spectrum (Graves et al., 1998).

According to Bushuk and Scanlon (1993), the miller plays a pivotal role between the wheat grasser / trader and the flour user. For the miller, selection of the right wheats and their optimal processing ensures that the specifications of the miller's customers are met, while at the same time permitting sufficient yield and through put that the mill can sustain a reasonable profit margin (Owens, 2001). The DIA has been employed, or has the potential to be employed, in a number of tasks within the mill to assist the miller in attaining the aforementioned objectives.

B- Bakery products: The ideal goal for online vision system analysis of bakery is that every product should be examined and this requires that DIA systems are not only accurate but they consistently maintain that accuracy at high speed. Despite such challenges, DIA has proven itself capable of being used on-line or at-line for many bakery applications and it has also been used off line in a research environment for examining the effect of changes in ingredients and processing factors on product quality (Scott, 1995, Psotka, 2001, Scanlon \& Sapirstein, 2002).

Schluentz et al. (2000) performed image analysis on scanning electron micrographs of dough to quantify the extent of dough development during which is critical to the final quality of most baked goods (Cauvain, 2001). Moreover, DIA measurement of the gas-cell size distribution in the section of the mixed dough has been reported (Campbell et al., 1991, Whitworth \& Alava, 1999). In bread making, development of optimal loaf shape, loaf volume and crust colour are three important quality attributes, each of which can be analyzed by DIA techniques (Riva \& Liviero, 2000).

Regardless of the image processing algorithms employed, DIA has shown itself to be sufficiently sensitive for quality evaluation in white pan breads, it can identify differences in image features that arise from the wheat source, use of ingredients such as emulsifiers and oxidizing agents, as well as from the effects of various processing conditions such as mixing time and proofing time (Bertrand et al., 1992, Zghal et al., 1999, Crowley et al., 2000, Zghal et al., 2001). Alternatively, DIA can be used to predict consumer (and/or baker) acceptability of the bread based on objective measurement of crumb cell structure (Wang \& Coles, 1994, Rogers et al., 1995).

Nuclear magnetic resonance (NMR), nuclear magnetic imaging (NMI) and spectroscopic studies were conducted on wheat flake biscuits during baking. Data revealed mapped spatial and temporal changes in moisture content across the biscuit during baking and resting (Duce et al., 1995).

C-Pasta and Noodles: The structure of pasta is largely governed by the presence of a structured protein network. Fardet et al. (1998) performed textural image analysis to determine effects of technological process on the protein network of pasta. The most significant difference in protein network structure was obtained with the autoclaved $20 \%$ proteinenriched samples.

Colour and appearance are prime quality requirements for high quality noodle products. As such, there is normally a preference for using patent flours because they produce noodles that are brighter and display fewer visible bran specks. Wet noodles under alkaline conditions are susceptible to time-dependent discolouration, giving the noodle a darkened appearance. The darking occurs not only on the overall matrix of a noodle surface but is quite commonly accelerated in localized areas throughout the noodle, resulting in spots that yield a mottled appearance. The reason for the appearance of dicoloured spots is not totally understood but is believed to originate from contaminating bran particles in the flour. It is a complex phenomenon that involves the enzyme polyphenol oxidase (PPO), phenolic components, alkaline oxidation and their subsequent autoxidation products (Baik et al., 1995, Hatcher et al., 1999).

The DIA was applied to numerically evaluate the time-dependent formation of dark areas (spots) on the noodle surface. The image analysis method presented by Hatcher et al. (1999) is capable of detecting areas of accelerated darkening that form spots on a wet noodle's surface with time. The method is extremely adaptable, using combinations of 
gray values and minimum size thresholds for establishing quality control criteria that are exempt from individual bias.

D- Chicken and meat: The tendency to lower production cost and thus to intensify poultry production methods results in a deterioration in meat quality, expressed principally by a lower water holding ability and water binding capacity, too light colour and poor palatability. From the economical point of view, it is quite important to find a certain and reliable method of detection, directly after slaughter, of meat of poor technological value. Tomasz et al. (2002) investigated relations between the colour of breast and thigh muscles in broiler chicken, measured by objective methods (reflex and digital image analysis) and chosen indicators of their technological value. Data indicated that protein content in meat is significantly related to colour lightness of mature meat, measured by the reflex method $\left(\mathrm{L}^{*}\right)$ and to colour component $G$, determined by DIA. Relations were also traced between colour lightness and both $\mathrm{pH}$ and the water holding ability of mature meat and between $b^{*}$ value (reflex method) and colour component B (DIA method) and the total content of heme pigments (Table 1). Accordingly, it is possible to use such meas- urements for the estimation of certain quality indicators of chicken meat.

For several decades, beef carcass evaluation for grading or research purposes has relied upon subjective visual scores (Video Image Analysis and Manually Taken Measurements). But, recently there has been a growing interest in new technologies capable of improving accuracy of estimates. Equations to predict weight and yield of beef pistol sub primal cuts were developed by Teria et al. (2003). The segmentation of selected parameters included: (1) Original digital image of a rib steak, (2) Total rib steak area, (3) Rib eye area, (4) Fat thickness, (5) Fat area, and (6) Fat area location. It is worth to mention that Video Image Analysis (VIA) and ultrasound measurements were used for a pre-slaughter evaluation of carcass qualitative trouts in cattle (Sakowski et al., 2002).

$\boldsymbol{E}$ - Cheese: Fat globules in cheese have been studied extensively using various microscopic techniques: light microscopy, scanning electron microscopy "SEM" and transmission electron microscopy "TEM" (Kimber et al., 1974, Brooker et al., 1975, Savello et al., 1989). Image contrast is a common limiting factor in conventional light microscopy. For SEM, fat globules in cheese are subjected to

Table 1: Chosen significant correlations between colour components determined by way of the reflex or DIA method and indicators of the technological quality of breast and drumstick muscles in chicken

\begin{tabular}{|c|c|c|c|c|}
\hline \multirow{2}{*}{ Muscle } & \multicolumn{2}{|c|}{ Correlation examined } & \multirow{2}{*}{$\begin{array}{c}\text { Correlation } \\
\text { coefficient }\end{array}$} & \multirow{2}{*}{$\begin{array}{c}\text { Linear regression } \\
\text { equation }\end{array}$} \\
\hline & Variable X & Variable Y & & \\
\hline Breast & $\mathrm{L}_{24}^{*}$ & Protein content & $-0.43^{\text {aа }}$ & $y=0.11 x+29.66$ \\
\hline Drumstick & $\mathrm{L}_{24}^{*}$ & Protein content & $-0.28^{\mathrm{a}}$ & $y=0.07 x+22.69$ \\
\hline Breast & $\mathrm{b}_{1}^{*}$ & Total content of hem pigment & $-0.40^{\text {aa }}$ & $\mathrm{y}=2.20 \mathrm{x}+31.11$ \\
\hline Breast & $\mathrm{b}_{48}^{*}$ & Total content of hem pigment & $-0.33^{\text {aa }}$ & $y=1.31 x+28.73$ \\
\hline Breast & $\mathrm{L}_{24}^{*}$ & $\mathrm{pH}_{24 \mathrm{hr}}$ & $-0.64^{\text {aa }}$ & $y=0.02 x+6.62$ \\
\hline Breast & $\mathrm{L}_{48}^{*}$ & Water holding ability & $0.52^{\text {aa }}$ & $y=0.71 x-25.15$ \\
\hline Drumstick & $\mathrm{L}_{24}^{*}$ & Water holding ability & $0.35^{\text {aa }}$ & $y=0.37 x-6.17$ \\
\hline Breast & $\mathrm{G}_{48}$ & Protein content & $-0.33^{\text {aa }}$ & $y=0.03 x+26.79$ \\
\hline Drumstick & $\mathrm{G}_{24}$ & Protein content & $-0.28^{\mathrm{a}}$ & $y=0.02 x+21.60$ \\
\hline Breast & $\mathrm{B}_{1}$ & Total content of hem pigment & $0.40^{\text {aa }}$ & $y=0.37 x-7.30$ \\
\hline Drumstick & $\mathrm{B}_{1}$ & Total content of hem pigment & $0.28^{\mathrm{a}}$ & $y=0.21 x+30.33$ \\
\hline
\end{tabular}

*L and $\mathrm{b} *$ : Hunter - colour units. aa : Correlation significant at $\mathrm{P}<0.05$. Ref. Tomasz et al. (2002).
$\mathrm{G}$ and $\mathrm{B}$ : Colour components determined by the DIA method a : Correlation significant at $\mathrm{P}<0.01$. 
organic solvents that are removed during the sample preparation, which may introduce artifacts. Although TEM offers high and low resolution to study cheese microstructure, samples are required to be dry, thin and conductive. If present, fine air pockets in the structure may remain unidentified and may be interpreted as fat globules. In addition to the limited sample size and the lengthy sample preparation time, SEM and TEM are expensive and time consuming to use, making these techniques less appealing for cheese analysis (Lee \& Morr, 1993).

According to Sutheerawattananonda et al. (1997), characteristics of fat in process cheese can be quantitatively analyzed by a fluorescence imaging techniques with minimum chemical manipulation and quick sample preparation. The technique takes advantages of fluorescence microscopy to distinguish fat particles from other cheese materials and offers good resolution. With the aid of computerized image processing system, tedious manual counting and analysis can be done accurately with a short and cover large area of sample.

\section{F- Chemical constituents and microstruc-}

ture: The study of colour or intensity of the points (pixels) in an image can be a way to obtain chemical information. Newman (1984, 1987) showed that image analysis makes it possible to estimate the fat and lean contents in meat and meat products. In the case of minced meats, the fat was differentiated from the lean using an ultraviolet light. In such conditions, fat fluoresces white in the visible range.

In the UV region, the movement of $\alpha$ amylase and the cell-wall breakdown during barley malting were visualized by taking advantage of the fluorescent effect of calcoflour (Gibbons, 1981).

Robert et al. (1992) performed a nearinfrared imaging spectroscopic system to identify three main components of wheat (bran, gluten and starch). The designed system permitted the recording of image between 900 and $1900 \mathrm{~nm}$ by steps of $50 \mathrm{~nm}$. In the segmented images, the percentages of well-classified pixels were 92 for bran, 95 for gluten and 99 for starch.

Confocol laser scanning microscopy (CLSM) is a noninvasive technique for evaluating the microstructure of foods and other materials. The CLSM provides several sequential subsurface layer of two-dimensional (2-D) images. An image processing algorithm was developed to reconstruct these 2-D layers into $\alpha$-dim-dimensional (3-D) network. Microstructure of fat globules in cheese was used as an example application. The validity of the image reconstruction algorithm was evaluated by processing several layered digital images of known shape and size. Differences between the original and reconstructed images were $2-5 \%$ in terms of object size and $1-8 \%$ in terms of shape (Ding \& Gunasekaran, 1998).

G- Microbiology: The synergistic interactions among microorganisms in biofilms were identified by the digital image analysis (DIA). It showed that reductions in biofilm plating efficiency were due to the loss of protection provided by two benzoate degrading strains of Pseudomonas fluorescens. Such a loss in protection was due to the spatial separation of the protective organisms from benzoate sensitive organisms during the dilution process. Communities were cultivated in flow cells irrigated with trypticase soy broth. When the effluent from these flow cells was plated on $0.15 \%$ benzoic acid, satellite colonies formed only in the vicinity of primary colonies (Karthikeyan et al., 1999).

A digital image analysis procedure was developed to measure the size and spatial distribution of the satellite colonies as a function of distance from the primary colony. The size of satellites served as a measure of growth and the number per unit area served as a measure of survival. At the three dilutions tested $\left(1 \times 10^{-1}, 1 \times 10^{-2}\right.$ and $\left.1 \times 10^{-3}\right)$, the size and concentration of satellite colonies varied inversely with distance from the primary colonies. When these measurements were plotted, the slopes were used to quantify the effect of bacterial association on the growth and survivability of satellites. In the absence of the primary colonies, satellites grew in axenic culture only at low benzoate concentrations. Thus, benzoate degrading organisms are capable of creating a protective microenvironment for other members of biofilm communities (Karthikeyan et al., 1999).

H- Bar coding : Bar coding is a form of artificial identifier. It is a machine readable 
code consisting of a pattern of black and white bars and space in defined ratios which represent alphanumeric characters. A sensor scans the bar code symbol and converts the visual image into an electrical signal. The optics involved may be a simple lens or fiberoptic transmission system which transmits the light signal to a detector located in a unit some distance away from the measurement point. The information encoded in the electrical signal of the bar code is then processed by a decoder which is programmed to obtain the desired information in a way similar to the way information from your eye is processed by your brain (Galbiati, 1990).

Each code bar label contains two quiet zones a start and a stop character, and a variable length data field up to 32 characters as illustrated in Figure (3). Each character is represented by a group of seven units four bars and three inter bar spaces. The ones are represented by bars and spaces two elements wide and zeros, by bars and spaces two elements wide and zeros, by bars and spaces one element wide. The form stopstant characters can be used to encode different types of information. The symbol contains different combinations of wide bars and/or wide spaces, according to the character. The quiet zone between symbols is ten times the width of the narrowest bar; hence, it is easy to identify different characters (Galbiati, 1990).

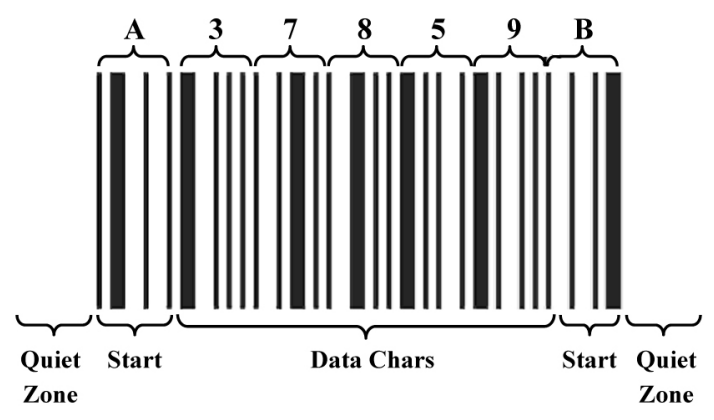

Fig. 3: Code bar symbol encoding “A37859B” Ref. Galbiati (1990).

Bar coding is the easiest, the most cost effective and the most reliable method of identifying and entering information into a computer based information system. Today, bar coding is the accepted method of acquiring tracking information on products both on the manufacturing line and in the distribution system (Galbiati, 1990).

\section{REFERENCES}

Baik, B.K., Czuchajowska, Z. \& Pomeranz, Y. 1995. Discolouration of dough for oriental noodles. Cereal Chem., 72: 198-205.

Berrtrand, D., LeGuerneve, C., Marion, D., Devaux, F.M. \& Robert, P. 1992. Description of the textural appearance of bread crumb by video image analysis. Cereal Chem., 69: 257-261.

Brooker, B.E., Hobbs, D.G. \& Turvey, A. 1975. Observations on the microscopic crystalline inclusions in cheddar cheese. J. Dairy Sci., 42: 341-348.

Bushuk, W. \& Scanlon, M.G. 1993. Wheat and wheat flours. In: Komel, B.S. \& Stauffer, C.F. (eds.). Advances in Baking Technology. pp. 1-19. Blackie Academic \& Professional , Glasgows.

Campbell, G.M., Rielly, C.D., Fryer, P.J. \& Sadd, P.A. 1991. The measurement of bubble size distribution in an opaque food fluid. Trans. Inst. Chem. Eng., C69: 67-76.

Cauvain, S.P. 2001. Breadmaking, In : Owens G. (ed.). Cereals Processing Technology. pp. 204-230. Woodhead Publishing Limited. Cambridge.

Crowley, P., Grau, H. \& Arendt, E.K. 2000. Influence of additives and mixing time on crumb grain characteristics of wheat bread. Cereal Chem., 77: 370-375.

Davies, E.R. 2000. Image Processing for the Food Industry. World Scientific Publishing Co., Singapore.

Dawson, A. 1986. Grading system out of date. The Manitoba Cooperator, 44: 1-9.

Ding, K. \& Gunasekaran, S. 1998. Three dimensional image reconstruction procedure for food afficrostructure evaluation. Artificial Intelligence Review, 12: 245-262.

Duce, S.L., Ablett, S., Darke, A.H., Pickles, J., Hart, C. \& Hall, L.D. 1995. Nuclear magnetic resonance imaging and spectroscopic studies of wheat flake biscuits during baking. Cereal Chem., 72: 105-108.

Fardet, A., Baldwin, P.M., Bertrand, D., Bouchet, B., Gallant, D.J. \& Barry, J.L. 1998. Textural image analysis of pasta protein networks to determine influence of technological processes. Cereal Chem., 75: 699704.

Galbiati, L.J. 1990. Machine Vision and Digital Image Processing Fundamentals. Prentice Hall International, Inc., New York, USA.

Gibbons, G.C. 1981. Visualization of $\alpha$-amylase movement and cell wall breakdown during malting-practical application of current research. J. Am. Soci. of Brewing Chemists, 39: 55-59. 
Gonzales, R.C. \& Wintz, P. 1987. Digital Image Processing. Second Editioin AddisionWesley Publishing Company Reading, Massachusetts. Menlo Park, California.

Graves, M., Smith, A. \& Batchelor, B. 1998. Approaches to foreign body detection in foods. Trends Food Sci. Technol., 9: 21-27.

Gunasekaran, S. \& Ding, K. 1994. Using computer vision for food quality evaluation. Food Technol., 48: 151-154.

Hatcher, D.W., Symons, S.J. \& Kruger, J.E. 1999. Measurement of the time dependent appearance of discoloured spots in alkaline noodles by image analysis. Cereal Chem., 76: 189-194.

Karthikeyan, S., Wolfaardt, G.M. \& Caldwell, D.E. 1999. Identification of synergistic interactions among microorganisms in biofilms by digital image analysis. Internatl. Microbio., 2: 241-250.

Keefe, P.D. \& Draper, S.R. 1986. The measurement of new characters for the identification of cultivar identification in wheat using machine vision. Seed Sci. Technol., 14: 715-724.

Kimber, A., Brooker, B.E., Hobbs, D.G. \& Prentice, J.H. 1974. Electron microscope studies of the development of structure in cheddar cheese. J. Dairy Res., 41: 389-396.

Kohler, J.M. 1991. Study of Commercial Grades of Canada Western Red Spring Wheat by Digital Image Processing. MSc. Thesis, University of Manitoba, Winnipeg, Canada.

Lee, S.Y. \& Morr, C.V. 1993. Fixation staining methods for examining microstructure in whipped cream by electron microscopy. J. Food Sci., 58: 124-127.

Majumdar, S. \& Jayas, D.S. 2000a. Classification of cereal grains using machine vision. II. Colour models. Trans. ASAE, 43: 16771680.

Majumdar, S. \& Jayas, D.S. 2000b. Classification of cereal grains using machine vision III. Texture models. Trans. ASAE, 43: 16811687.

Newman, P.B. 1984. The use of video image analysis for quantitative measurement of fatness in meat. II. Comparison of VIA, visual assessment and total chemical fat estimation in commercial environment. Meat Science, 10: 161-166.

Newman, P.B. 1987. Meat grading by image analysis. Proceedings of "The objective measurement of Food Quality" Conference 12-13 Nov., 1987. Chipping Campdun, U.K. pp. 90-98.
Newman, M., Sapirstein, H.D., Shwedyk, E. \& Bushuk, W. 1987. Discrimination of wheat class and variety by digital image analysis of whole grain samples. J. Cereal Sci., 6: 125-132.

Owens, W.G. 2001. Wheat, corn and coarse grains milling In : Owens, G. (ed.) Cereals Processing Technology. pp. 27-52. Woodhead Publishing Limited. Cambridge.

Psotka, J. 2001. Digital image analysis of finished food products. Cereal Foods World, 46: 2023.

Riva, M. \& Liviero, S. 2000. Image analysis approach to characterize the bread cooking kinetic. Industrie Alimentari, 39: 953-960.

Robert, P., Bertrand, D., Devaux, M.F. \& Sire, A. 1992. Identification of chemical constituents by multivariate near-infrared spectral imaging. Anal. Chem., 64: 664-667.

Rogers, D., Day, D.D. \& Olewnik, M.C. 1995. Development of an objective crumb-grain measurement. Cereal Foods World, 40: 498-501.

Sakowski, T., Sloniewski, K. \& Reklewski, Z. 2002. Using digital image analysis and ultrasound measurements for a preslaughter evaluation of carcass qualitative traits in cattle. Animal Science Papers and Reports, 20: 111-123.

Sapirstein, H.D. 1995. Variety identification by digital image analysis. In : Wrigley, C. W. (ed.). Identification of Food-Grain Varieties. pp. 91-130. American Association of Cereal Chemist, Inc. St. Paul, MN.

Sapirstein, H.D. \& Kohler, J.M. 1995. Physical uniformity of graded raikar and vessel shipments of Canada Western Red Spring wheat determined by digital image analysis. Can. J. Plant Sci., 75: 363-369.

Sapirstein, H.D. \& Kruger, J.E. 1995. Rapid objective prediction of sprout damage in wheat by digital image analysis of transilluminated kernels. In: Noda, K. and Mares, D.J. (eds.). Proceeding of Seventh International Symposium on Pre-Harvest Sprouting in Cereals, pp. 71-77. Center for Academic Societies, Osaka.

Savello, P.A., Ernstrom, C.A. \& Kalab, M. 1989. Microstructure and melability of model process cheese made with rennet and acid casein. J. Dairy Sci., 72: 1-11.

Scanlon, M.G. \& Sapristein, H.D. 2002. Digital image analysis for quality assurance in the wheat-to-bread supply chain. In : Ng, P. K. W., Wrigley, C.W. (eds.): Wheat Quality Elucidation- The Bushuk Legacy- American Association of Cereal Chemists, Inc. St. Paul, Minnesota, USA. 
Schatzki, T.F. \& Fine, T.A.B. 1988. Analysis of radiograms of wheat kernel for quality control. Cereal Chem., 65: 233-239.

Schluentz, E.J., Steffe, J.F. \& Ng, P.K.W. 2000. Rheology and microstructure of wheat dough developed with controlled deformation. J. Texture Stud., 31: 41-54.

Scott, A.J. 1995. On-line inspection of bakery and snack products. Cereal Foods World, 40: 15-18.

Sutheerawattananonda, M., Fulcher, R.G., Martin, F.B. \& Bostain, E.D. 1997. Fluorescence image analysis of processed cheese manufactured with trisodium citrate and sodium chloride. J. Dairy Sci., 80: 620-627.

Symons, S.J. \& Fulcher, R.G. 1988. Determination of wheat kernel morphological variation by digital image analysis. I. Variation in Eastern Canadian milling quality wheat. J. Cereal Sci., 8: 211-218.

Teria, G.A., Tinois, E., Lotufo, R. deA. \& de Felicio 2003. Digital-image analysis to predict weight and yields of boneless subprimal beef cuts. Scientia Agricola, 60: 403-408.
Tomasz, F., Miroslaw, S., \& Krzysztof, D. 2002. Colour measurements as a method for the estimation of certain chicken meat quality indicators. Electronic Journal of Polish Agricultural Universities. www. Ejpau.media.pi.

Wang, I. \& Coles, G.D. 1994. Objective measurement of bread crumb texture. SPIE Proc., Optics in Agriculture, Forestry and Biological Processing, 2345: 85-91.

Whitworth, M.B. \& Alava, J.M. 1999. The imaging and measurement of bubbles in bread doughs. In : Campbell, G.M., Webb, C., Pandiella, S.S. \& Nivanjan, K. (eds.) Bubbles in Food, pp. 221-231. Egon Press. St. Paul, M.N.

Zghal, M.C., Scanlon, M.G. \& Sapirstein, H.D. 1999. Prediction of bread crumb density by digital image analysis. Cereal Chem., 76: 734-742.

Zghal, M.C., Scanlon, M.G. \& Sapirstein, H.D. 2001. Effects of flour strength, baking absorption, and processing conditions on the structure and mechanical properties of bread crumb. Cereal Chem., 78: 1-7. 


\section{تطبيقات التحليل التصويري الرقمي \\ في تقويم جودة الأغذية : نظرة شاملة}

\section{محمدمحمود يوسف، هلفئ علي مسن ألبو غربية، نسمة نبل الحداد}

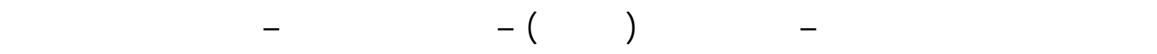
الإسكندرية - جمهورية مصر العربية - جلمعة الينكةر

في السنوات الأخيرة تعظظم دور التحلل التصويري الرقمي (DIA) في مناحِ تكنولوجية متعدة لشتملت على

مجالات الفضاء والاتصالات والإنشعار عن بعد والطب مُ لخيراً مجالات تحللل وتصنيع ومراقبة جودة الأغذية. تشير الظة image (صورة تتعكس على مرةّ) إلى ششة الضوء light intensity في محورين x, قيمتا هني المحورين على الفراغ الهنهي للطيف spectrum locus المعلن brightness لهذ الصورة image عند فئد هذه التطة. ويمكن اعتبار التصوير الرقمي digital image يمثلبة بنيلن matrix يحدد الصف row والعمود column فيه فطة معينة في الصورة image، بينما تحدد قيمة عناصر هذا البنيلن matrix elements المقالبل مستوى اللون

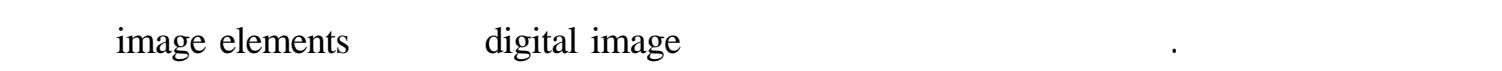
picture elements أو الـ ـ pixels أو الـ ـ pels، ويعتبر المصطلحلن الأخيران الأذثرشيوعَّف في هذا الصدد. وقد تزاليد لستخدلم التحليل التصويري الرقمي في عنيدمن الطبيقتسواع في الزراعة لتحديد المسلحت

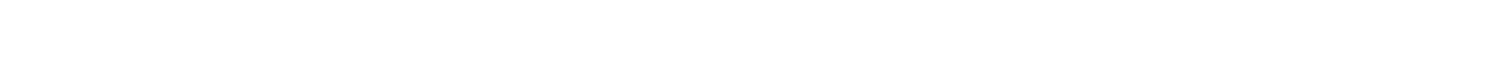
مراقبة الجوةة. وفي مجل الغذاء فإنه يمكن لستخدلم التحليل التصويري الرقمي في القرقة بين الحبوب المختلفة

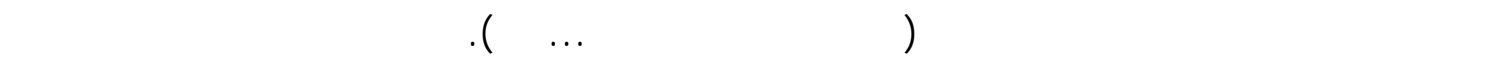

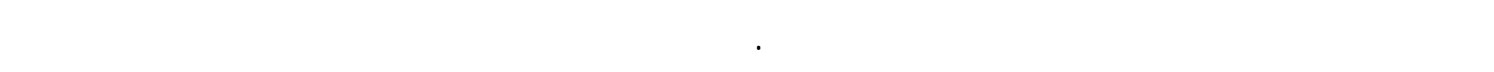

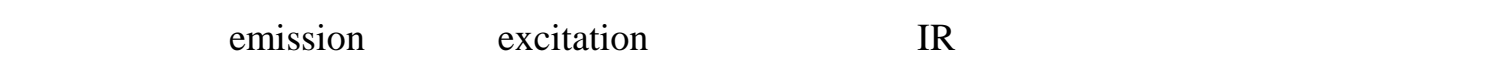
image المتحصل عليها للفريق بين المكونت الرئيسية للحبوب (النشا، الجلوتين، الردة). وعنطريق درلسةشدة اللون للقطا (pixels) في الـ ـ image فإنه يمكن الحصول على معلومات كيمياوية

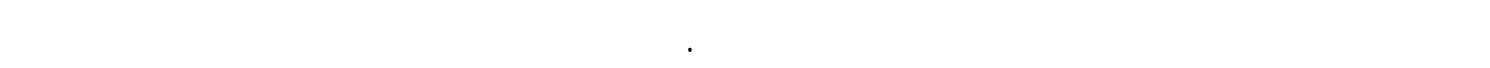

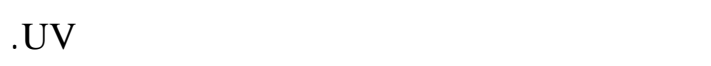
ويعتبر التشفير (التكويد) الخطي أو العمودي bar coding لحد الظبيقل المهمة للتحليل التصويري الرقمي. وهذا الظلم للتثفير يعتبر وحدة صناعية للتمييز، ويتكون ظلم التثفير من ملكينة قراعة للثفرة لسكانر) نقوم من خلال برنلمج كمبيوتر بترجمة الخطوط (الأعمة) للسوداء والفراغات البينية إلى إثشارات

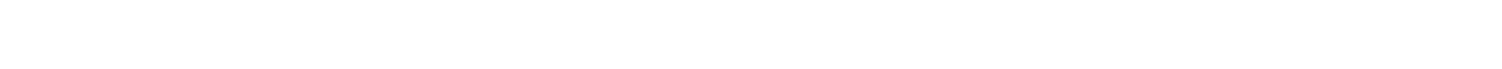

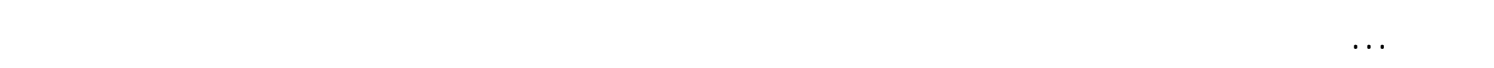

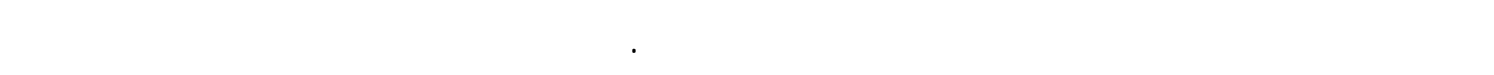
لإضفافسعر السلعة المباعة إلى حصيلة المركز التجاري. 